\title{
РОЗРОБКА ВИРОБНИЧОЇ ПРОГРАМИ ТА ОБ'ЄМНО-ПЛАНУВАЛЬНИХ РІШЕНЬ ПРИМІЩЕНЬ ДЛЯ ДВОФАЗНОЇ ТЕХНОЛОГІЇ ВИРОЩУВАННЯ МОЛОДНЯКУ СВИНЕЙ
}

\author{
Іванов Володимир Олександрович \\ доктор сільськогосподарських наук, профессор \\ Інститут свинарства і агропромислового виробництва НААН \\ ORCID: 0000-0001-86537092 \\ E-mail: vl-iva9008@ukr.net
}

Засуха Людмила Володимирівна

кандидат сільськогосподарських наук

Інститут свинарства і агропромислового виробництва НААН

ORCID: 0000-0001-7481-1242

E-mail: ludmila10031985@gmail.com

\author{
Григоренко Валерій Леонідович \\ здобувач \\ Інститут свинарства і агропромислового виробництва НАAН \\ ORCID: 0000-0003-2385-5063 \\ E-mail: grigorenkovaleri63@gmail.com
}

\begin{abstract}
У статті показані основні переваги сучасної промислової двофразної технології та умови для оптимального утримання й годівлі свиноматок і поросят. Для їі успішного впровадження розроблена виробнича програма та об'ємнопланувальні рішення приміщень для вирощування молодняку на промисловій свиноффермі малого типу потужністю виробництва 4000 голів молодняку в рік. Наведено показники виробничої програми виробниитва свинини для фрерми малого типу. Розраховані основні технологічні параметри потокового виробництва: кількість технологічних груп, тривалість перебування тварин у групі, число днів санітарного розриву. Показано розрахунок головомісиь для холостих, умовно-поросних, явно-поросних, підсисних свиноматок, поросят-сисунів, поросят на дорощуванні в маточних станках, ремонтного молодняку на промисловій фермі, за умов реалізації поросят в 65 днів. Наведено об'ємно-планувальні рішення, приміщення № 1 - для утримання кнурів, холостих, умовно-поросних, поросних свиноматок і приміщення, № 2 - для утримання підсисних свиноматок і поросят-сисунів та їх дорощування до 65-денного віку. Крім того, наведено креслення загального вигляду станків для опоросу і вирощування молодняку свиней за сухого ( СП-4ФС) і комбінованого ( СП-4ФК) типу годівлі. В роботі приводиться коротка характеристика обладнання для утримання, годівлі, вентиляиії, гноєвидалення та очищення забрудненого повітря. Наведена порівняльна характеристика ефективності проектно-технологічних рішень приміщення для утримання підсисних свиноматок і молодняку свиней. Зокрема, в ній показано кількість станкомісць, оборот станкомісць, кількість дорощеного молодняку, отриманого з одного станкомісия за рік, валовий вихід продукиії на одне станкомісце за рік, вихід продукції на 1 м² виробничої площі за базового та нового варіантів. Розроблені проектно-технологічні і об'ємнопланувальні рішення приміщення для опоросу свиноматок і утримання відлучених поросят до 65-денного віку з новим станковим обладнанням для промислової свинофрерми потужністю 4000 голів дають можливість отримати валовий вихід продукції на одне станкомісие 12,95 и за рік та вихід продукції на 1 м² виробничої площі 3,07 и (проти 10,44 и за рік і 1,39 и у базовому варіанті, відповідно).
\end{abstract}

Ключові слова: технологія, об'ємно-планувальні рішення, приміщення, обладнання, кнури, свиноматки, поросята, молодняк, продуктивність.

DOI: https://doi.org/10.32845/bsnau.lvst.2020.3.7

Постановка проблеми, аналіз останніх досліджень, актуальність та мета. Аналіз розвитку світового свинарства висвітлив ряд важливих проблем пов'язаних з промисловим виробництвом свинини. Вони стосуються благополуччя тварин та якості продукції $[8,9,10]$, які безпосередньо залежать від застосування тих чи інших технологій.

В сучасному свинарстві, в основному, застосовуються два типа технологій - трифазна і двофазна $[3,5,6]$. За трифазною технологією поросят-сисунів утримують в свинарниках-маточних, після відлучення від свиноматок їх переводять в свинарники для дорощування, а потім - у приміщення для відгодівлі. В результаті зміни трьох типів приміщень та дворазового перегрупування у тварин виникає стресовий стан, що призводить до зниження потенційної продуктивності
$[1,2]$. Двофразна технологія виробництва свинини менш розповсюджена, але $\epsilon$ оптимальнішою, так як поросята утримуються в одному приміщенні в маточних станках до 90-120денного віку $[3,4,7]$. За такою технологією зменшується число перегрупувань i конфліктних ситуацій, що позитивно впливає на розвиток молодняку та ефективність оплати корму продукцією. Головною умовою сучасної промислової двофразної технології $є$ поточність і ритмічність виробництва. Крім того, двофазна технологія повинна бути забезпечена спеціальними маточними станками, які забезпечують комфортні умови утримання й годівлі свиноматок і поросят в період підсису та дорощування останніх. Мета роботи - розробка потокової виробничої програми, об'ємно-планувальних рішень приміщень і обладнання для двофазної технології вирощування молодняку свиней в умовах малих фрерм.

Вісник Сумського національного аграрного університету 
Матеріали та методи досліджень. Розробці потокової виробничої програми передували дослідження двофазної технології, які були проведенні в умовах фермерського господарства «Екофарм» Херсонської області, що спеціалізується на розведенні гібридних свиней. В процесі проведення досліджень були використані економіко-статистичні, зоотехнічні та графічні методи.
Результати досліджень та обговорення. Показники розробленої виробничої програми, об'ємно-планувальні рішення свинарника-маточника і свинарника-відгодівельника для фермерських господарств, які спеціалізуються на вирощуванні і реалізації молодняку свиней у 65 днів за двофазною технологією наведено в таблицях 1-4 та рисунках 1-3.

Показники виробничої програми виробництва свинини для ферми малого типу

\begin{tabular}{|c|c|}
\hline Показник & Значення показника \\
\hline Потужність виробництва , голів & 4000 \\
\hline Тривалість холостого періоду, днів & 15 \\
\hline Рівень аварійних опоросів, \% & 10 \\
\hline Кількість опоросів на свиноматку в рік & 2,3 \\
\hline Багатоплідність, голів, у тому числі: & 12,4 \\
\hline основних маток & 13 \\
\hline маток, що перевіряються & 11 \\
\hline Рівень прохолосту, \% & 20 \\
\hline Великоплідність, кг & 1,4 \\
\hline Тривалість підсисного періоду, днів & 28 \\
\hline Тривалість утримання поросят в маточних станках всього, днів & 65 \\
\hline Середня жива маса поросяти на кінець підсисного періоду, кг & 8,4 \\
\hline Середньодобовий приріст поросят-сисунів на кінець підсисного періоду, г & 250 \\
\hline Тривалість утримання поросят в маточних станках після відлучення, днів & 37 \\
\hline Середньодобовий приріст від народження до кінця утримання у маточних станках, г & 451 \\
\hline Жива маса поросят на кінець дорощування у маточних станках (у 65 днів) & 28 \\
\hline Жива маса ремонтних свинок перед заплідненням, кг & 140 \\
\hline Падіж поросят-сисунів, \% (на початок дорощування) & 10 \\
\hline Санітарний брак поросят-сисунів, \% (на початок дорощування) & 3 \\
\hline Падіж поросят на дорощуванні, \% & 3 \\
\hline Санітарний брак поросят на дорощуванні, \% & 2 \\
\hline Рівень бракування стада кнурів і свиноматок, \% & 40 \\
\hline Кількість першоопоросок у стаді, \% & 30 \\
\hline Кількість основних маток у стаді, \% & 70 \\
\hline Кількість повноцінних опоросів свиноматок за ритм & 32 \\
\hline Свинарник-маточник розрахований на утримання в ізольованих секціях, гол. & 32 \\
\hline Тривалість перебування явно-поросних маток в маточних станках до опоросу, днів & 5 \\
\hline Тривалість перебування умовно-поросних маток в індивідуальних станках, днів & 35 \\
\hline Тривалість перебування явно поросних маток в групових станках, днів & 75 \\
\hline Коефріцієнт понаднормової кількості ремонтних свинок & 2 \\
\hline Тривалість періоду дорощування в маточних станках, днів & 37 \\
\hline Вік першого осіменіння свинок, місяців & 8 \\
\hline Тривалість репродуктивного циклу у свиноматок, днів & 158 \\
\hline
\end{tabular}

Відповідні розрахунки наведено в таблицях 2 і 3.

Основні технологічні параметри потокового виробництва

\begin{tabular}{|c|c|c|c|c|}
\hline \multirow[b]{2}{*}{ Технологічна група } & \multicolumn{2}{|c|}{$\begin{array}{c}\text { Тривалість } \\
\end{array}$} & \multirow[b]{2}{*}{ Кількість груп } & \multirow{2}{*}{$\begin{array}{c}\text { Кількість тварин } \\
\text { в групі, гол. }\end{array}$} \\
\hline & $\begin{array}{c}\text { перебування } \\
\text { тварин у групі, дні }\end{array}$ & $\begin{array}{l}\text { Санітарного } \\
\text { розриву, дні }\end{array}$ & & \\
\hline $\begin{array}{l}\text { Холості свиноматки } \\
\text { (буфрерна група) }\end{array}$ & ( & 更 & 2 & 38 \\
\hline Умовно-поросні свиноматки & 35 & 7 & 3 & 44 \\
\hline Явно-поросні свиноматки & 75 & 9 & 6 & 35 \\
\hline Підсисні свиноматки & 84 & 14 & 8 & 32 \\
\hline Поросята-сисуни & 28 & 0 & 0 & 396 \\
\hline Поросята (дорощування в маточних станках) & 37 & 0 & 0 & 345 \\
\hline Ремонтний молодняк & 0 & 14 & 1 & 5 \\
\hline
\end{tabular}


Розрахунок головомісць на промисловій фермі за умов реалізації поросят в 65 днів

\begin{tabular}{|l|c|}
\hline \multicolumn{1}{|c|}{ Технологічна група } & Необхідно головомісць \\
\hline Кнури-плідники & 8 \\
\hline Холості свиноматки (буфрерна група) & 44 \\
\hline Умовно-поросні свиноматки & 132 \\
\hline Явно-поросні свиноматки & 210 \\
\hline Підсисні свиноматки з поросятами & 224 \\
\hline Ремонтний молодняк & 5 \\
\hline
\end{tabular}

На підставі проведених розрахунків нами розроблено об'ємно-планувальні рішення для ферми промислового типу потужністю виробництва 4000 голів на рік, яка містить два виробничі приміщення: 1 - для утримання кнурів, свиноматок

і ремонтного молодняку свиней, 2 - для утримання підсисних свиноматок з поросятами і їх дорощування до 65-денного віку (рис. 1, 2)

$$
\mathrm{A} \rightarrow 1
$$$$
\mathrm{B} \rightarrow
$$
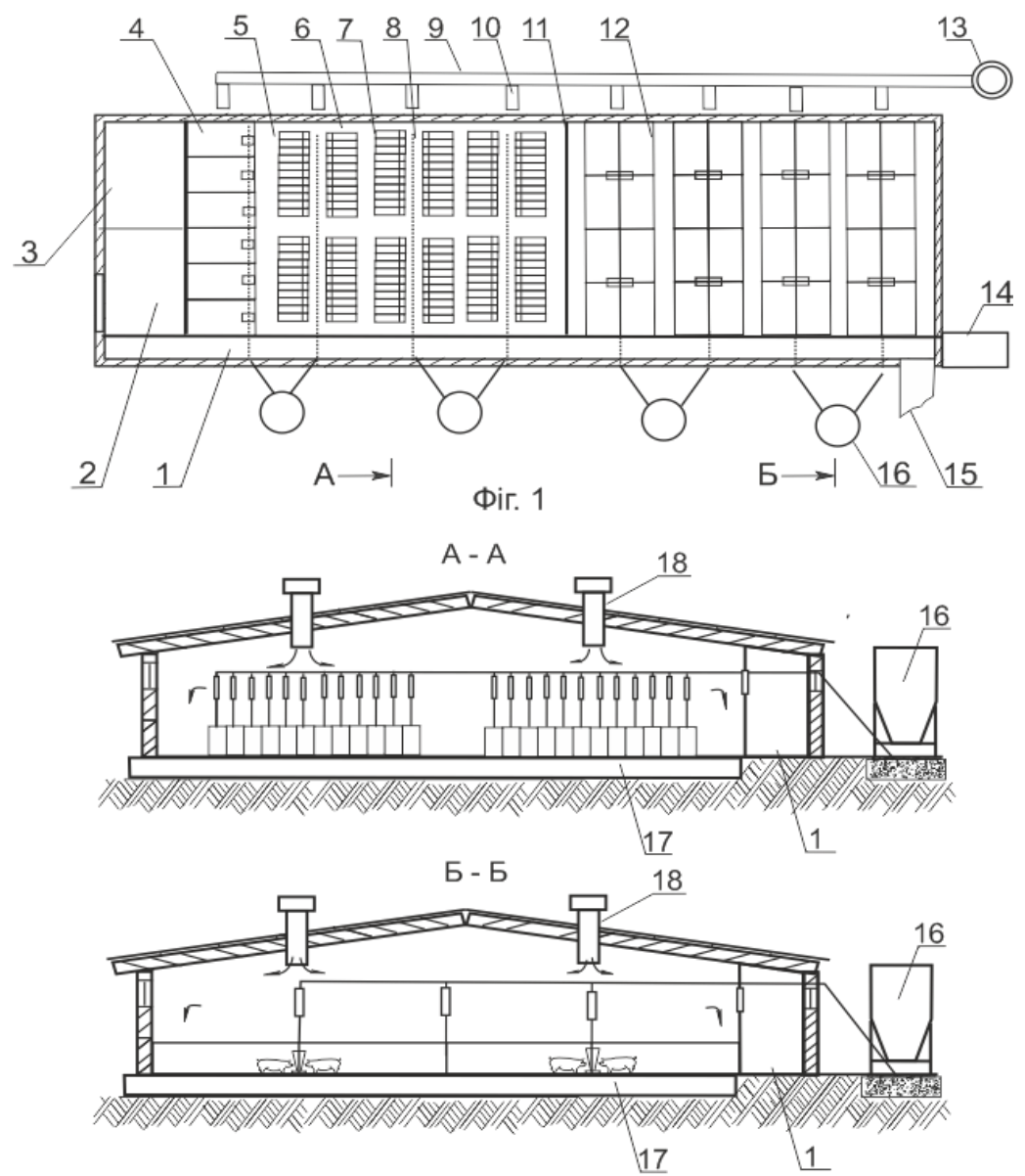

Фіг. 2

Puc. 1. Приміщення № 1 для утримання кнурів, холостих, умовно-поросних, поросних свиноматок:

1 - внутрішня галерея (1300 мм); 2 - манеж для взяття сперми; 3 - лабораторія; 4 - індивідуальний станок для кнурів (3750х2200 мм); 5 - поздовжній прохід; 6 - боковий прохід (1200 мм); 7 - індивідуальний станок для умовно-поросних свиноматок (2400х68); 8 - кормороздавач спіральний; 9 - збірний колектор повітря; 10 - витяжний підлоговий вентилятор; 11 - секційна перегородка із ПВХ; 12 - груповий станок (4000х4500); 13 - станція очистки повітря; 14 - рампа для завантаження тварин; 15 - зовнішня сполучна галерея; 16 - бункер сухих кормів; 17 - гнойова ванна; 18 - нагнітаючий вентилятор.

Приміщення № 1 (78х18 м) поділене на три ізольовані секції. У першій секції розташовано пункт осіменіння з манежем для взяття сперми та лабораторія для оцінки її якості й приготування флаконів для осіменіння.

У другій секції розташовано вісім індивідуальних станків для кнурів-плідників і 132 індивідуальні станки для умовно-поросних свиноматок.
Мікроклімат в приміщенні підтримується за допомогою системи повітрявидалення за рахунок підрешітчастих вентиляторів.

Напування свиней всіх виробничих груп передбачається з соскових і чашкових напувалок. У групових станках вони встановлюються на ґратчастих перегородках суміжних станків, а в індивідуальних - над годівницями.

Гній видаляється у ванни, які перекриті решітками. 
Глибина лотків 0,6 м. Під лотками секцій з ухилом у 3 \% прокладений колектор із труб ПХВ діаметром 0,25 м, який з'єднаний 3 ваннами патрубками через трійники з герметичними пробками.

Холості, поросні свиноматки та ремонтний молодняк утримуються в групових станках $(4000 \times 4500$ м) із самогодівницями, які сполучені спіральним транспортером через дозатори. Підлога у станку має суцільну і решітчасту частини.
Площа підлоги у груповому станку на одну голову становить

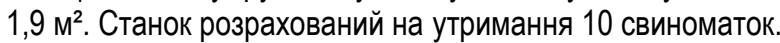

Свиноматок за 5-7 днів до опоросу переганяють у приміщення № 1 по сполученій зовнішній галереї і розміщують в індивідуальних станках СП-4ФС або СП-4ФК. Приміщення № 2 містить 224 маточних станка, у яких підсисні свиноматки знаходяться впродовж 28 днів.

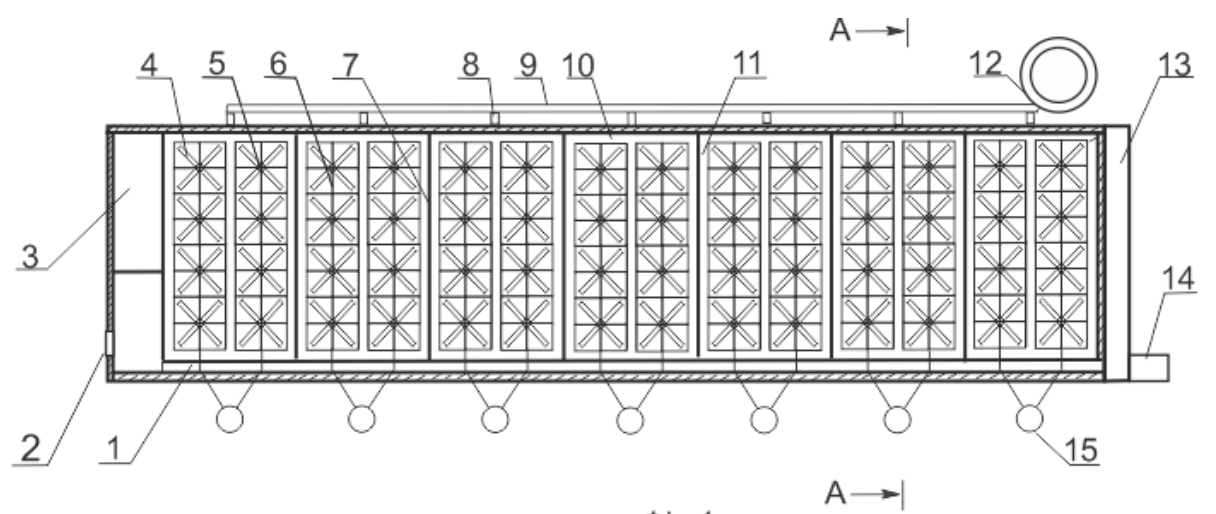

Фіг. 1

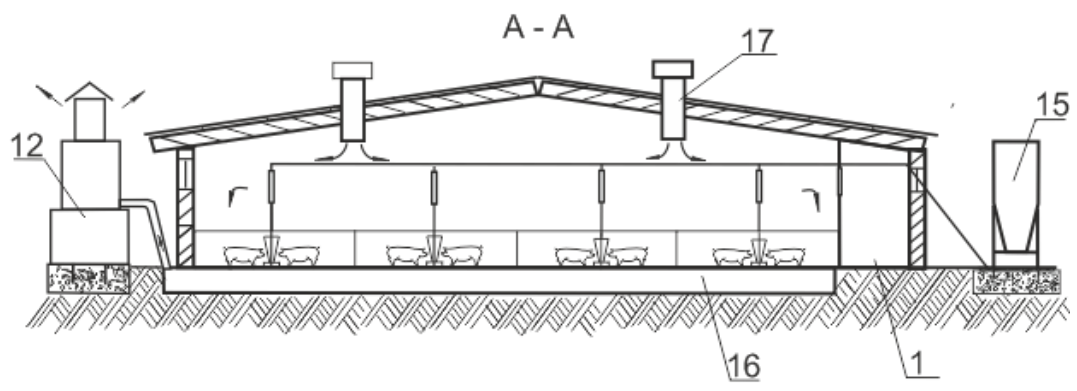

Фіг. 2

Puc. 2. Приміщення № 2 (18x84 м) для утримання 224 підсисних свиноматок з поросятами і їх дорощування до 65денного віку: 1 - галерея (1300 мм); 2 - двері; 3 - кімната для оператора; 4 - станок СП-4ФК (4100х400); 5 - самогодівниця; 6 - кормороздавач спіральний; 7 - секційна перегородка із ПВХ; 8 - витяжний підлоговий вентилятор; 9 - колектор витяжний;

10 - боковий прохід (1100 мм); 11 - повздовжній прохід (1200 мм); 12 - станція очистки повітря, 13 - сполучна галерея; 14 - рампа для завантаження тварин; 15 - бункер сухих кормів; 16 - гнойова ванна; 17 - нагнітаючий вентилятор.

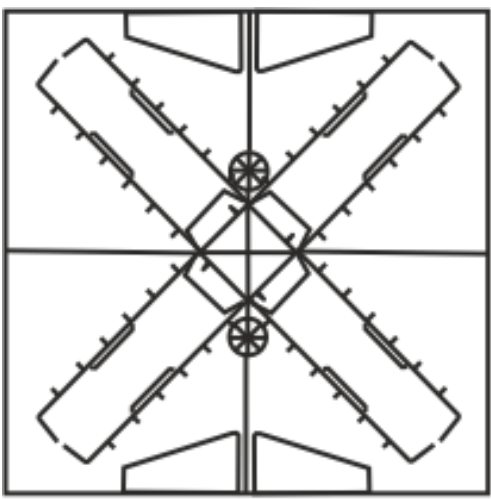

Фіг. 1

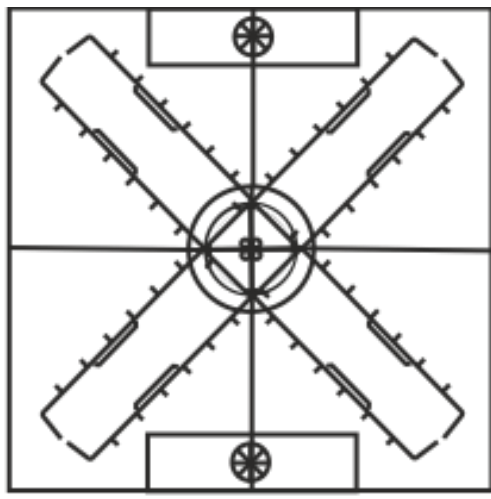

Фіг. 2

Puc. 3. Загальний вигляд станків для опоросу і вирощування молодняку свиней за сухого (фіг. 1, СП-4ФС) і комбінованого (фіг. 2, СП-4ФК) типу годівлі.

Після закінчення підсисного періоду свиноматок виганяють із станків, а далі через сполучену зовнішню галерею заганяють у приміщення № 1, де розміщують у групових станках до виявлення охоти.

У маточнику встановлена вакуумна система гноєви- далення з ваннами, над якими розташована пластикова підлога. Система кормороздавачі представлена поперечним спіральним транспортером, який подає корм в годівниці із бункера сухих кормів (БСК). Напування свиноматок, поросят-сисунів і відлученого молодняку здійснюється із соскових авто- 
напувалок. Система вентиляції - припливно-витяжна. Особливістю об'ємно-планувальних рішень приміщення для утримання підсисних свиноматок з поросятами і їх дорощування до 65-денного віку є розподіл на ізольовані секції за допомогою перегородок товщиною 0,3 см із ПВХ; наявність бокової галереї, компактне розміщення станкового обладнання на гнойових ваннах та станції для очищення забрудненого повітря.

Порівняльна характеристика ефективності проектно-технологічних рішень приміщення для утримання підсисних свиноматок і молодняку свиней

\begin{tabular}{|c|c|c|c|}
\hline Показник & Базовий варіант & Новий варіант & До базового, \pm \\
\hline Довжина, м & 84 & 84 & - \\
\hline Ширина, м & 18 & 18 & - \\
\hline Висота, м & 4,25 & 4,25 & - \\
\hline Загальна площа свинарника, м² & 1515 & 1512 & - \\
\hline Площа 1 станкомісця, м² & 7,5 & 4,2 & $-3,3$ \\
\hline Кількість станкомісць & 104 & 224 & +120 \\
\hline Виробнича площа , м² & 780 & 941 & +161 \\
\hline Оборот станкомісць при санрозриві 14 дні, разів & 4,3 & 4,3 & - \\
\hline Кількість дорощеного молодняку отриманого з одного станкомісця за рік, голів & 43,86 & 45,40 & $+1,54$ \\
\hline Жива маса при знятті з дорощування, кг* & $23,82 \pm 0,43$ & $28,54 \pm 0,49^{* * *}$ & $+4,72$ \\
\hline Валовий вихід продукції на одне станкомісце за рік, ц & 10,44 & 12,95 & $+2,51$ \\
\hline Вихід продукції на 1 м² виробничої площі, ц & 1,39 & 3,07 & 1,68 \\
\hline
\end{tabular}

*Примітка: за результатами попередніх досліджень.

На нашу думку, наведені вище розрахунки двофазного потокового виробництва свинини та проектно-конструктивні рішення приміщень дають можливість при невеликих інвестиціях забезпечити будівництво свиноферми малого типу на 4000 голів молодняку в рік.

Висновки. Розроблені проектно-технологічні і об'ємно-планувальні рішення приміщення для опоросу свиноматок і утримання відлучених поросят до 65-денного віку з

Таблиця 4

новим станковим обладнанням для промислової свиноферми потужністю 4000 голів дають можливість отримати валовий вихід продукції на одне станкомісце 12,95 ц за рік та вихід продукції на 1 м² виробничої площі 3,07 ц (проти 10,44 ц за рік і 1,39 ц у базовому варіанті, відповідно), що дають підставу для впровадження їх у виробництво.

\section{Список використаної літератури:}

1. Волощук В. М. Теоретичне обірунтування і створення конкуренто-спроможних технологій виробництва свинини: Монографрія. Полтава, 2012. 350 с.

2. Комлацкий В. И., Величко Л. Ф. Биологические основы производства свинины (курс лекций). Учебное пособие. КубГАУ. Краснодар, 2010. 175 C.

3. Калюга В. В., Базыкин В. И., Трифанов А. В. Сравнение двухфазного и трехфазного бесстрессовых способов содержания свиней на стадии концептуального проектирования малых свиноферм / Технологии и технические средства механизированного производства продукции растениеводства и животноводства. 2018. С. 188-197.

4. Костенко С. В. Научное обоснование двухфазной технологии выращивания свиней: дис. ... канд. с.-х. наук: 06.02 .04 / Костенко Светлана Владимировна. Краснодар, 2004. 140 с.

5. Лихач В. Я. Обгрунтування, розробка та впровадження інтенсивно-технологічних рішень у свинарстві: автореф. дис. ... д-ра с.-г. наук: спец. 06.02.04 / Лихач Вадим Ярославович. Миколаїв. 2016. 38 с.

6. Свинарство: монографія; за ред. В. М. Волощука. К., Аграрна наука. 2014. 592 с.

7. Трифанов А. В., Базыкин В. И. Предпосылки к разработке технологического решения для безстрессового перемещения свиней. Технологии и технические средства механизированного производства продукции растениеводства и животноводства. 2019. С. 295-301.

8. The Pork Industry at a Glance. https://porkgateway.org/wp-content/uploads/2015/07/quick-facts-book1.pdf

9. John J. McGlone. The Future of Pork Production in the World: Towards

Sustainable, Welfare-Positive Systems //Animals 2013, 3, P. 401-415; doi:10.3390/ani3020401

10. Mike D. Tokach, Bob D. Goodband, Travis G. O'Quinn Performance-enhancing technologies in swine production. Animal Frontiers, Vol. 6, Issue 4. 2016, P. 15-21.

\section{References:}

1. Voloshchuk, V. M. 2012. Teoretychne obgruntuvannia i stvorennia konkurento-spromozhnykh tekhnolohii vyrobnytstva svynyny: Monohrafiia. Poltava, 350.

2. Komlackij, V. I. and Velichko L. F., 2010. Biologicheskie osnovy proizvodstva svininy (kurs lekcii). Uchebnoe posobie. KubGAU. Krasnodar, 175.

3. Kaljuga, V. V., Bazykin, V. I. and Trifanov, A. V., 2018. Sravnenie dvuhfaznogo i trehfaznogo besstressovyh sposobov soderzhanija svinej na stadii konceptual'nogo proektirovanija malyh svinoferm / Tehnologii i tehnicheskie sredstva mehanizirovannogo proizvodstva produkcii rastenievodstva i zhivotnovodstva. pp. 188-197. 
4. Kostenko, S. V. Nauchnoe obosnovanie dvuhfaznoj tehnologii vyrashhivanija svinej: dis. ... kand. s.-h. nauk: 06.02 .04 / Kostenko Svetlana Vladimirovna. Krasnodar, 2004. 140.

5. Lykhach, V. la., 2016. Obgruntuvannia, rozrobka ta vprovadzhennia intensyvno-tekhnolohichnykh rishen u svynarstvi: avtoref. dys. ... d-ra s.-h. nauk: spets. 06.02.04 / Lykhach Vadym Yaroslavovych. Mykolaiv, 38.

6. Svynarstvo: monohrafiia / za red. V. M. Voloshchuka. K., Ahrarna nauka. 2014. 592.

7. Trifanov, A. V. and Bazykin, V. I., 2019. Predposylki k razrabotke tehnologicheskogo reshenija dlja besstressovogo peremeshhenija svinej. Tehnologii $\mathrm{i}$ tehnicheskie sredstva mehanizirovannogo proizvodstva produkcii rastenievodstva $\mathrm{i}$ zhivotnovodstva. pp. 295-301.

8. The Pork Industry at a Glance. https://porkgateway.org/wp-content/uploads/2015/07/quick-facts-book1.pdf

9. John J. McGlone., 2013. The Future of Pork Production in the World: Towards Sustainable, Welfare-Positive Systems. Animals, Vol. 3, pp. 401-415; doi:10.3390/ani 3020401

10. Mike, D., Tokach, Bob D., Goodband, Travis G. and O'Quinn. 2016. Performance-enhancing technologies in swine production. Animal Frontiers, vol. 6, issue 4. pp. 15-21.

Ivanov Vladimir Alexandrovich, Doctor of Agricultural Sciences, Professor

Zasukha Liudmyla Vladimirovna, PhD of Agricultural Sciences

Hryhorenko Valerii Leonidovych, PhD student

Institute of Pig Breeding and Agroindustrial Production of NAAS (Poltava, Ukraine)

Development of production program and spatial planning solutions for two-phase technology of growing young pigs

The article shows the main advantages of modern industrial two-phase technology and conditions for optimal keeping and feeding of sows and piglets. With the aim of successfully introducing the two-phase technology, a production program and spaceplanning solutions for premises have been developed for raising young animals on a small-type industrial pig farm with a production capacity of 4000 young animals per year. Indicators of the production program of pork production for a small farm are given. The main technological parameters of continuous production were calculated: the number of technological groups, the duration of the stay of animals in the group, the number of days of the sanitary break. Shown is the calculation of machine places for single, conditionally pregnant, obviously pregnant, suckling sows, suckling piglets, weaning piglets in brood pens, replacement young animals on an industrial farm under the conditions of selling piglets at 65 days. Presents space-planning solutions, room No. 1 for keeping boars, single, conditionally pregnant, gestating sows, and room No. 2 for keeping suckling sows, suckling piglets and growing them up to 65 days of age. The article presents space-planning solutions, room No. 1 for keeping boars, single, conditionally pregnant, gestating sows, and room No. 2 for keeping suckling sows, suckling piglets and growing them up to 65 days of age. In addition, drawings of a general view of pens for farrowing and rearing young pigs for dry (SP-4FS) and combined (SP-4FK) type of feeding are shown. The paper provides a brief description of equipment for keeping, feeding, ventilation, manure removal and purification of polluted air. Provides a comparative characteristic of the effectiveness of design and technological solutions of the premises for keeping suckling sows and young pigs. In particular, it shows the number of machine stations, the turnover of the machine place, the number of overgrown young animals received from one e machine place per year, the gross output per one machine place per year, the output per $1 \mathrm{~m}^{2}$ of production area. Developed design, technological and space-planning solutions for the farrowing room for sows and the maintenance of weaning pigs up to 65 days of age with new pen equipment for an industrial pig farm with a capacity of 4000 heads make it possible to obtain a gross output of products per machine place of 12.95 centners per year and an output per $1 \mathrm{~m}^{2}$ of production area of 3.07 centners (versus 10.44 centners per year and 1.39 centners in the basic version, respectively).

Key words: technology, space-planning solutions, premises, equipment, boars, sows, piglets, young growth, productivity.

Дата надходження до редакції: 27. 10.2020 р. 